\title{
Etika Komunikasi Siswa dalam Pembelajaran Daring Melalui Aplikasi Whatsapp
}

\section{Eko Prabowo ${ }^{1}$, Nur Fajrie ${ }^{2}$, dan Deka Setiawan ${ }^{3}$}

1,2,3 PGSD, Universitas Muria Kudus, Kudus, Indonesia

\section{ART ICLE INF O}

Article history:

Received August 05, 2021

Revised August 07, 2021

Accepted September 30, 2021

Available online October 25, 2021

Kata Kunci:

Pembelajaran Daring, Whatsapp, Etika Komunikasi

Keywords:

Online Learning, Whatsapp

Communication Ethics

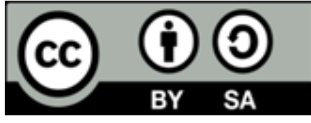

This is an open access article under the CC BY-SA license.

Copyright () 2021 by Author. Published by Universitas Pendidikan Ganesha.

\section{A B S T R A C T}

\begin{abstract}
A B S T R A K
Proses pembelajaran daring dilakukan melalui media berupa whatsapp, google classroom, google meet mengharuskan peserta didik dalam berkomunikasi secara aktif dengan guru. Dalam proses komunikasi tersebut banyak peserta didik yang tidak sopan saat bertanya tugas dengan guru. Tujuan penelitian ini untuk menganalisis bentuk-bentuk etika komunikasi siswa dalam pola pembelajaran daring melalui aplikasi WhatsApp. Jenis penelitian ini yaitu penelitian kualitatif. Subjek penelitian sebanyak 6 siswa diambil secara acak dengan teknik simple random sampling. Teknik pengumpulan data meliputi wawancara, observasi dan dokumentasi. Analisis data yang digunakan yaitu penelitian lapangan yang bersifat naratif. Hasil penelitian membuktikan bahwa etika berkomunikasi siswa selama pandemi Covid 19 dalam pembelajaran daring dengan aplikasi WhatsApp pada siswa kelas IV tergolong kurang baik. Siswa jarang memberikan respon terhadap informasi materi atau tugas yang diberikan oleh guru. Tata penulisan siswa dalam memberikan respon di WhatsApp berupa emoticon dan stiker sudah tepat, namun tanda baca pada konteks kalimat yang dituliskan siswa belum tepat. Gaya bahasa yang digunakan siswa dalam memberikan respon di WhatsApp menggunakan bahasa bilingual (campuran) yaitu Bahasa Indonesia dan Bahasa Jawa.
\end{abstract}

The online learning process is carried out through WhatsApp, Google Classroom, and Google Meet, requiring students to communicate with the teacher actively. In the communication process, many students are not polite when asking for assignments with the teacher. This study aimed to analyze the ethical forms of student communication in online learning patterns through the WhatsApp application. This type of research is qualitative research. The research subjects were six students taken randomly with a simple random sampling technique. Data collection techniques include interviews, observation, and documentation. Analysis of the data used is narrative field research. The study results prove that students' communication ethics during the Covid 19 pandemic in online learning with the WhatsApp application for fourth-grade students are not good. Students rarely respond to material information or assignments given by the teacher. The students' writing order in responding to WhatsApp in the form of emoticons and stickers is correct, but the punctuation marks in the context of the sentences written by students are not correct. The language style used by students in responding on WhatsApp uses a bilingual (mixed) language, namely Indonesian and Javanese.

\section{PENDAHULUAN}

Pembelajaran merupakan bagian inti dari suatu proses pendidikan yang dilaksanakan di sekolah. Pembelajaran merupakan sistem yang berupa gabungan dari komponen-komponen yang berhubungan satu sama lain untuk mencapai tujuan pendidikan (Dumitrescu et al., 2014; Fitria et al., 2018; Kintu et al., 2017). Pembelajaran yang dilaksanakan disekolah diharapkan mampu melatih kemampuan otak, meningkatkan kreativitas, serta membentuk karakter siswa (Gurung, 2020; Idris \& Sida, 2019; Prasetyo et al., 2020). Peserta didik harus diajar, dibina dan dilatih menjadi manusia yang kokoh, mempunyai moral dan etika baik kepada semua orang sebagai salah satu landasan menjalin hubungan antar sesama manusia. Namun saat ini proses pembelajaran mengalami perubahan sebagai dampak pandemi Covid-19 
(Lyócsa et al., 2020; Tamboto et al., 2021; Yulia, 2020). Pendidikan menjadi salah satu hal yang di perhatikan oleh pemerintah dimasa pandemi Covid-19 ini (Maulana, 2021; Sukendro et al., 2020). Kebijakan yang di ambil dalam bidang pendidikan adalah melaksanakan pembelajaran secara daring (Dewi \& Khotimah, 2020; Yulianingsih et al., 2020). Hal ini dilakukan sebagai upaya pencegahan penyebaran virus Covid-19. Pembelajaran daring merupakan salah satu metode pembelajaran online atau dilakukan melalui jaringan internet (Dyah, 2020; Fitriyani \& Sari, 2020; Mustofa et al., 2019; Rahma \& Pujiastuti, 2021).

Pembelajaran daring merupakan sebuah pembelajaran yang dilakukan dalam jarak jauh melalui media berupa internet dan alat penunjang lainnya seperti telepon seluler dan computer (Goudeau et al., 2021; Jiang et al., 2021; Owusu-Fordjour et al., 2020). Salah satu aplikasi yang dapat digunakan untuk melaksanakan pembelajaran daring adalah whatsapp (Chang et al., 2020; Sa'diyah, H., Hastuti, A. F., \& Prasetiyo, 2020). Aplikasi whattsap memudahkan peserta didik dalam melakukan komunikasi dengan guru. Pembelajaran daring sangat berbeda dengan pembelajaran tatap muka, pembelajaran daring lebih menekankan pada ketelitian dan kejelian peserta didik dalam menerima dan mengolah informasi yang disajikan secara online (Agustina et al., 2021; Arrosagaray et al., 2019; Jogezai et al., 2021). Pembelajaran daring memberikan kesempatan kepada siswa untuk belajar lebih mandiri (Hwang et al., 2020; Kkese, 2020). Pembelajaran daring memberikan keluwesan waktu dan tempat belajar, misalnya belajar dapat dilakukan di kamar, ruang tamu dan sebagainya serta waktu yang disesuaikan misalnya pagi, siang, sore atau malam. Selain itu juga dapat mengatasi permasalahan mengenai jarak, misalnya siswa tidak harus pergi ke sekolah dahulu untuk belajar. Tidak ada batasan dan dapat mencakup area yang luas (Andarwulan et al., 2021; Pujiasih, 2020; Riaz, 2018). Dengan fasiltas yang tersedia dan alat bantu yang bisa digunakan akan membuat pembelajaran daring berkualitas. Pembelajaran daring akan membantu peserta didik untuk memahami materi yang bersifat abstrak, mengembangkan pembelajaran kolaborasi, penalaran dan kegiatan pemecahan masalah (Arnott \& Yelland, 2020; Glassman et al., 2021). Melalui pembelajaran secara daring diharapkan peserta didik tetap mampu belajar secara maksimal guna mencapai tujuan pembelajaran.

Namun yang terjadi dilapangan pembelajaran daring memiliki kekurangan yang dapat menghambat proses pembelajaran (Arizona et al., 2020; Hutauruk \& Sidabutar, 2020; Putria et al., 2020). Adpaun hambatan yang terjadi selama pembelajaran daring yaitu: guru kesulitan dalam mencari strategi yang digunakan saat pembelajaran daring, kurangnya fasilitas yang dimiliki siswa dalam mendukung pembelajaran daring, sering terjadinya gangguan koneksi internet sehingga menghambat dalam proses pembelajaran daring, anak sulit untuk fokus pada pembelajaran karena suasana rumah yang kurang kondusif (Primasari \& Zulela, 2021; Sari, 2015). Selain itu proses pembelajaran daring dilakukan melalui media berupa whatsapp, googleclassroom, google meet mengharuskan peserta didik dalam berkomunikasi secara aktif dengan guru (Anugrahana, 2020; Fikri et al., 2021). Dalam proses komunikasi tersebut banyak peserta didik yang tidak sopan saat bertanya tugas dengan guru, misalnya langsung bertanya tanpa mengucapkan salam seolah-olah merka bertanya kepada temannya. Hal ini perlu menjadi sorotan karena guru adalah pendidik yang harus dihormati oleh siswa agar mereka segan dan displin dalam belajar. Hal ini yang menyebabkan dalam pembelajaran daring tetap memperhatikan etika dalam berkomunikasi. Etika dalam berkomunikasi penting dilakukan sebagai upaya untuk menciptakan kehidupan yang lebih bermakna (Djuwita, 2017; Junaidi, 2018; Khaerunnnisa \& Pamungkas, 2018).

Guru dan siswa harus memperhatikan prinsip-prinsip dalam model pembelajaran daring. Hal ini bertujuan agar pembelajaran daring melalui media sosial WhatsApp dapat mencapai tujuan yang diinginkan yaitu dapat meningkatkan kemampuan siswa dalam memahami konten pembelajaran (Abroto et al., 2021; Mulyono et al., 2021; Trisnani, 2017). Etika berkomunikasi dalam media sosial WhatsApp mengutamakan sikap jujur dan terus terang, hubungan yang harmonis, ketepatan pesan, menghindari kecurangan, dan konsistensi pesan verbal (Daheri et al., 2020; Sa'diyah, et al., 2020). Etika berkomunikasi di internet dikenal dengan istilah dengan Netiquette yang artinya aturan dan tata cara penggunaan internet sebagai alat komunikasi atau pertukaran data antar-sekelompok orang dalam sistem yang termediasi. Sama seperti aturan etika di dunia nyata, netiquette juga mendorong para pengguna untuk taat pada aturan etis dan moral yang baik meskipun tidak tertulis, pengguna harus berusaha menciptakan ruang bersama yang nyaman, tentram, dan damai (Fahrimal, 2018). Dengan hal ini, berkomunikasi di media sosial dan dunia nyata masih tetap ada etika, norma dan aturannya.

Temuan penelitian sebelumnya menyatakan bahwa etika dalam berkomunikasi sangat penting bagi siswa untuk membentuk karakter (Fauziyyah, 2019; Mutiani, 2021). Temuan penelitian lainnya juga menyatakan bahwa etika komunikasi sangat penting dipahami oleh siswa sehingga siswa terbiasa menggunakan bahasa yang sopan ketika sedang berbicara (Afifah, 2019; Junaidi, 2018; Sarjana \& Khayati, 2017). Berdasarkan hal tersebut maka pentingnya etika berkomunikasi dalam pembelajaran daring. Penelitian ini bertujuan untuk menganalisis gambaran etika komunikasi siswa di kelas IV selama 
pembelajaran melalui aplikasi WhatsApp. Penelitian ini diharapkan akan memberikan gambaran etika berkomunikasi siswa terhadap guru selama pembelajaran daring berlangsung melalui media sosial aplikasi WhatsApp. Selanjutnya, guru dapat memberikan arahan mengenai etika komunikasi yang baik untuk siswa dalam melakukan komunikasi ketika pembelajaran daring menggunakan aplikasi WhatsApp berlangsung.

\section{METODE}

Penelitian ini menggunakan metodologi kualitatif yang bersifat naratif dengan jenis penelitian lapangan (field research). Penelitian ini menggambarkan analisis etika berkomunikasi siswa kelas IV SDN 2 Tajungsari, Pati selama pembelajaran daring melalui media sosial aplikasi WhatsApp. Subjek penelitian ini adalah 6 siswa dari 15 siswa di kelas IV SDN 2 Tajungsari yang diambil secara acak dengan teknik simple random sampling. Teknik pengambilan data ini menggunakan screenshoot percakapan siswa di WhatsApp dalam menanggapi informasi materi atau tugas yang diberikan guru. Pengumpulan data dilakukan dengan teknik observasi langsung. Pelaksanaan penelitian dilakukan dengan wawancara secara terbuka. Wawancara terbuka dilakukan tanpa membuat pedoman wawancara yang disusun secara sistematis dan lengkap. Pedoman wawancara yang digunakan hanya berupa garis-garis besar permasalahan yang akan ditanyakan. Dalam studi ini juga dilakukan dokumentasi terhadap chat peracakapan siswa dengan guru di WhatsApp group dengan cara screenshoot.

Teknik analisis data dilakukan melalui tiga tahap, yaitu: pertama, reduksi data, dalam hal ini peneliti menganalisis hasil screenshoot chat tanggapan dan respon siswa di WhatsApp dengan guru. Kedua, menyajikan data yaitu menyajikan data dalam bentuk gambar dan uraian singkat; dan Ketiga, menarik kesimpulan. Langkah-langkah dalam penelitian ini terdiri dari tiga tahap, yaitu: tahap persiapan; tahap pelaksanaan; dan tahap akhir. Tahap persiapan yang dilakukan, yaitu: pertama, melakukan pra penelitian pada siswa kelas IV SD. Kedua, mencari data screenshoot chat siswa di WhatsApp group. Ketiga, menyusun pedoman wawancara untuk guru dan siswa. Pada tahap pelaksanaan, diantaranya; mengobservasi chat siswa dengan guru di WhatsApp group kelas IV; mendokumentasikan chat siswa ketika pembelajaran daring di WhatsApp group dengan cara screenshoot; dan mewawancarai guru dan siswa mengenai etika berkomunikasi pada pembelajaran daring. Pada tahap akhir adalah peneliti menganalisis data screenshoot chat siswa dengan guru ketika pembelajaran daring melalui aplikasi WhatsApp. Langkah terakhir adalah penyusunan data, yakni penyususnan kata-kata hasil wawancara hasil observasi, dan dokumen-dokumen berdasarkan kategorisasi yang sesuai dengan masalah penelitian. Selanjutnya, berdasarkan data yang diperoleh akan dikembangkan melalui pencarian data selanjutnya. Dalam penelitan ini, data akan dicatat dengan apa adanya tanpa campur tangan dari teori yang terbaca. Peneliti berusaha mencari makna inti dari etika komunikasi siswa saat pembelajaran daring. Hal ini dilakukan dalam rangka memahami perilaku siswa dalam konteks pikiran. Pada saat wawancara dilakukan analisis terhadap jawaban yang diwawancarai. Apabila jawaban sumber data belum memuaskan, maka peneliti akan melakukan wawancara lagi sampai data dianggap kredibel. Aktivitas dalam analisis data dilakukan secara interaktif dan berlangsung secara terus menerus sampai tuntas.

\section{HASIL DAN PEMBAHASAN}

\section{Hasil}

Siswa pada dasarnya merupakan pelaku dalam pergerakan pembaharuan generasi penerus bangsa dalam membangun bangsa tanah air kearah yang lebih baik yaitu generasi penerus yang memiliki etika. Etika merupakan alat kontrol siswa dalam melakukan suatu tindakan yang dilakukan. Etika dapat menjadi gambaran bagi siswa dalam melakukan sesuatu yang baik atau yang buruk. Oleh karena itu, makna etika harus dipahami lebih dalam lagi dan dilaksanakan dalam lingkungan siswa. Siswa sebagai anak didik sekolah pastinya akan berkomunikasi dengan guru. Hal ini, tatakrama atau etika sangat berperan penting dalam menentukan tingkah laku sikap siswa terhadap guru. Dalam kegiatan sehari-hari ketentuan etika sopan santun ini berpengaruh terhadap cara bicara, cara memperlakukan, cara menghubungi, dan menanggapi tugas atau materi pembelajaran yang diberikan. Lembaga pendidikan/sekolahan merupakan salah satu pembentuk etika siswa. Berikut beberapa data yang ditemukan dalam penelitian tentang etika berkomunikasi siswa terhadap guru pada pola pembelajaran daring melalui aplikasi media sosial WhatsApp selama pandemi Covid-19 berdasarkan dokumentasi dan hasil wawancara dengan informan. Komunikasi memerlukan sikap dalam proses kegiatannya. Sikap dalam komunikasi secara daring yang baik adalah adanya feedback (umpan balik) maupun respon yang baik antara siswa dan guru. Selain itu, bentuk sikap yang dapat diberikan siswa pada guru adalah berperilaku sopan dalam mengirim pesan di WhatsApp. 


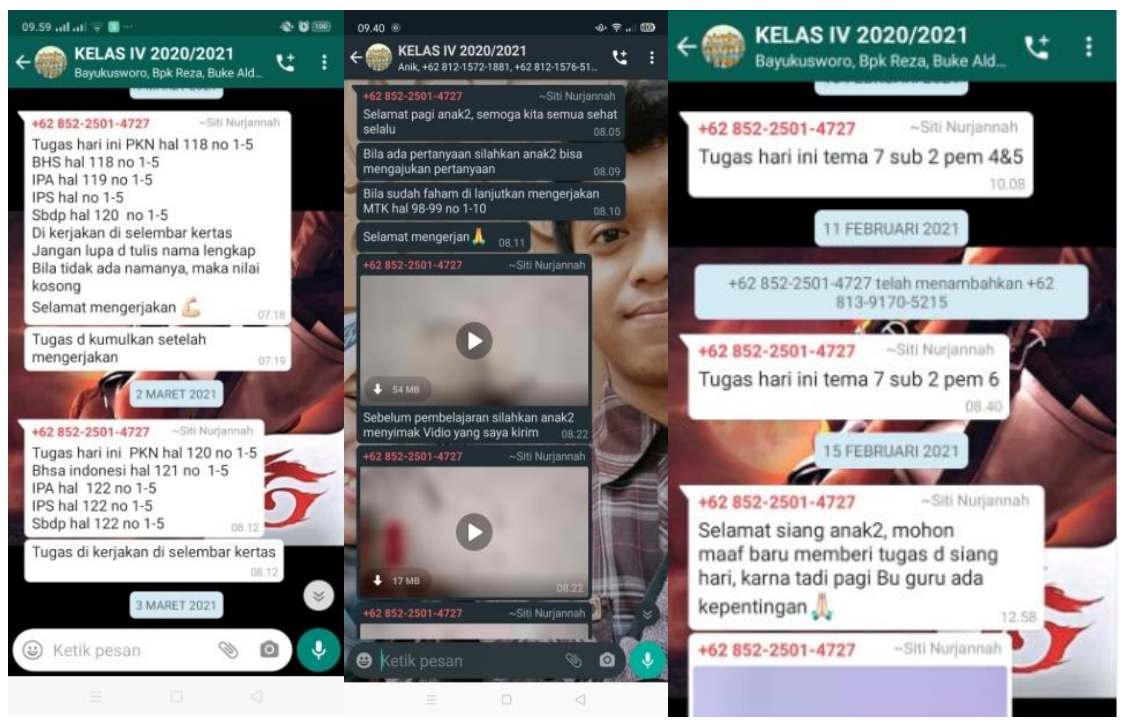

Gambar 1. Screenshoot chat tidak ada feedback dari siswa

Berdasarkan Gambar 1, informasi yang diberikan guru di WhatsApp group tidak diberikan respon ataupun feedback (umpan balik) sama sekali oleh siswa. Tertera pada cuplikan chat yang dikirimkan oleh guru kelas 4 secara berturut-turut tidak ada respon sama sekali dari siswa. Selain itu, berdasarkan hasil observasi yang dilakukan peneliti di dalam percakapan WhatsApp group kelas 4, siswa tidak pernah mengucapkan terimakasih setelah pembelajaran daring selesai. Siswa juga tidak melakukan kegiatan salam sapa kepada guru ketika pembelajaran daring dimulai. Hasil ini menunjukkan sikap yang baik dalam memberikan respon seperti salam pembuka dan penutup ataupun memberikan feedback (umpan balik) terhadap tugas atau materi yang diberikan oleh guru melalui aplikasi media sosial WhatsApp. Sehingga dapat disimpulkan bahwa sikap siswa dalam etika berkomunikasi di WhatsApp group adalah kurang baik. Hal ini diperkuat dengan hasil wawancara dengan guru kelas IV mengenai sikap berkomunikasi siswa di WhatsApp group. Alasan siswa tidak selalu merespon atau memberikan feedback saat pembelajaran daring adalah karena siswa sudah paham mengenai tugas atau materi yang diberikan.

Tata penulisan merupakan cara menyusun kalimat yang baik tanpa adanya pengurangan kata (disingkat). Tata penulisan menjadi hal terpenting dalam bertutur di aplikasi media sosial WhatsApp. Tata penulisan di WhatsApp menimbulkan makna tuturan sekaligus mempengaruhi nilai kesantunan karena pada dasarnya nilai kesantunan dalam berkomunikasi di WhatsApp terlihat dari pilihan kata yang digunakan. Penyusunan kalimat dalam berkomunikasi melalui aplikasi media sosial WhatsApp dengan guru sebaiknya menggunakan kalimat yang utuh tanpa adanya pengurangan kata. Penggunaan tanda baca koma (.), titik (.), tanda tanya (?), dan tanda seru (!) dalam percakapan di WhatsApp juga harus diperhatikan, supaya pesan yang diberikan semakin mudah untuk dimengerti. Hasil analisis data, tata penulisan AD kurang tepat dalam Kamus Besar Bahasa Indonesia (KBBI). Kalimat yang dituliskan Andrian Dwi pada Gambar 4 adalah "Bu tema 1 ataw tema5". AD melakukan kesalahan dalam penulisan kata "ataw", sedangkan dalam KBBI yang benar adalah "atau". Selain itu AD juga tidak memisah penulisan antara huruf dan angka, yaitu pada percakapan "tema1 dan tema5". Konteks kalimat yang ditulis AD adalah kalimat tanya, namun AD tidak memberikan tanda baca yang tepat. Kalimat yang seharusnya ditulis oleh $\mathrm{AD}$ adalah "Bu, tema 1 atau tema 5?".

Siswa dalam merespon percakapan guru di WhatsApp juga dapat memberikan emoticon atau stiker untuk mengekspresikan emosi tanggapannya di WhatsApp. Selain penyusunan kalimat dan tanda baca, emoticon dalam WhatsApp juga mampu memberikan makna tuturan tanpa harus menuliskan kata. Emoticon adalah kombinasi simbol- simbol berbentuk teks tertulis yang disusun dari karakter ASCII sebagai simbol atau lambang untuk mengungkapkan luapan perasaan. Dengan kata lain, emoticon itu merupakan bahasa emosi yang diwujudkan dengan bentuk ikon atau lambang. Emoticon yang ditambahkan oleh siswa pada percakapan di WhatsApp digunakan untuk mendukung makna tuturan verbal. Berdasarkan hasil analisis data diketahui bahwa siswa D menanggapi informasi yang diberikan guru dengan kata "njeh bu". Tanggapan yang diberikan D sudah tepat, akan tetapi tata penulisan D kurang tepat karena penulisan "njeh" yang benar dalam tingkatan bahasa Jawa krama yaitu: nggeh, nggih, inggih, njih, dan injih. Selain itu, R juga ikut menanggapi informasi yang diberikan guru dengan menyatakan "njeh cikgu.....". Kalimat yang dituliskan oleh $\mathrm{R}$ tidak baku dan tergolong santai karena menggunakan kata 
"cikgu" yang artinya guru. Kata "cikgu” adalah bahasa Melayu Malaysia sehingga kata yang dituliskan R tidak sesuai dengan KBBI.

Salah satu bentuk feedback yang diberikan siswa pada chat guru di WhatsApp (Gambar 5) yaitu dengan menuliskan emoticon. Emoticon yang diberikan siswa pada guru diantaranya, emoticon A mempunyai makna memohon kepada lawan bicara (guru), sedangkan emoticon $\bullet$ mempunyai makna rasa bahagia. Selanjutnya, emoticon $\Leftrightarrow$ mempunyai makna ada suatu hal yang kocak, emoticon mempunyai makna terkejut dan keprihatinan dan emoticon of mempunyai makna setuju. Tata penulisan emoticon yang ditulis siswa di WhatsApp dalam menanggapi chat guru sudah tepat dalam mengungkapkan sebuah perasaan yang mewakilinya, sehingga siswa tidak perlu ada penjelasan secara tertulis. Selain itu penggunaan emoticon dapat menguatkan nilai kesantunan dalam berkomunikasi di WhatsApp. Hal ini sesuai dengan hasil penelitian sebelumnya yang menyatakan bahwa penggunaan simbol-simbol atau emoticon gambar yang sering kali digunakan dengan tujuan mengungkapkan sebuah makna perasaan atau makna pesan secara tidak langsung (non verbal), sehingga tidak memerlukan penjelasan secara tertulis untuk memahaminya (Oktario et al., 2019).

Siswa A memberikan respon pada percakapan guru di WhatsApp menggunakan kalimat dan stiker. Dalam percakapan di WhatsApp guru memberikan salam pembuka kepada siswa sebelum pembelajaran dimulai. Ibu Siti Nurjannah menyatakan "selamat pagi anak2, semoga kita semua sehat selalu". Siswa A memberikan respon menggunakan stiker dengan kata "Amiin". Tanggapan yang diberikan siswa A terhadap salam pembuka yang diberikan guru sudah tepat. Selain siswa A, siswa lain tidak memberikan tanggapan sama sekali terhadap salam pembuka yang diberikan oleh guru. Kemudian, guru memberikan apersepsi kepada siswa dengan menyatakan "sebelum pembelajaran silahkan anak2 menyimak video yang saya kirim". Siswa A memberikan respon terhadap apersepsi yang diberikan guru di WhatsApp menggunakan kalimat "nggeh bu guru???". Tata tulis pada kalimat siswa A kurang tepat, karena konteks kalimat yang ditulis siswa A merupakan pernyataan bukan pertanyaan. Sehingga kalimat siswa A tidak seharusnya menggunakan tanda baca tanya (?). Siswa A juga menanggapi lagi apersepsi dari guru menggunakan stiker berupa gambar orang dengan kata "siap!!". Stiker yang diberikan siswa A sudah sesuai dengan konteks kalimat apersepsi yang diberikan guru di WhatsApp.

Gaya bahasa merupakan penggunaan kata-kata dalam berbicara maupun menulis untuk mempengaruhi pembaca atau pendengar. Gaya bahasa menjadi cara siswa untuk mengungkapkan pikiran melalui bahasa secara khas yang memperlihatkan jiwa dan kepribadiannya. Gaya bahasa di WhatsApp berbentuk non verbal (tertulis). Dalam memberi tanggapan di WhatsApp terkadang siswa belum bisa membedakan kata dan bahasa apa yang tepat digunakan untuk berkomunikasi, terlebih berkomunikasi menggunakan media sosial. Dalam kehidupan sehari-hari, siswa sering menggunakan bahasa daerah yaitu bahasa jawa. Hal ini karena lingkungan pergaulan siswa lebih mengenal bahasa daerah daripada bahasa Indonesia baku. Siswa terkadang memberikan tanggapan komunikasi guru di WhatsApp menggunakan bahasa daerah bercampur dengan bahasa Indonesia (bilingual). Hal ini karena kurangnya pemahaman siswa terhadap konsepsi bahasa Indonesia baku. Gaya bahasa di WhatsApp berbentuk non verbal (tertulis). Dalam memberi tanggapan di WhatsApp terkadang siswa belum bisa membedakan kata dan bahasa apa yang tepat digunakan untuk berkomunikasi, terlebih berkomunikasi menggunakan media sosial. Oleh karena itu, siswa tidak dapat menerapkan dan memilih kosakata yang tepat untuk digunakan berkomunikasi secara formal dengan guru terlebih ketika menggunakan aplikasi WhatsApp.

Guru memberikan tugas di WhatsApp dengan menyatakan "Tugas hari ini tema 4 sub 3 pem 3\&4". Sementara itu siswa OA menanggapi percakapan guru dengan bertanya "mkstnya pye gk ngerti aku". Kalimat yang ditulis OA tidak baku, karena kalimat yang dituliskan menggunakan bahasa daerah dan tidak sesuai dengan ejaan yang benar (disingkat), selain itu bahasa yang digunakan tergolong santai (non formal). Lalu siswa Al juga ikut menanggapi dengan kalimat "mruput bu ( ^ ". Selain itu, siswa KN juga menanggapi dengan kalimat "tugase gasik". Bahasa yang ditulis Al dan KN termasuk bahasa daerah (jawa) dan tergolong santai. Penggunaan emoticon yang ditulis siswa dapat mendukung makna tuturan dan menguatkan nilai kesantunan berbahasa jika digunakan dengan tepat. Contohnya adalah emoticon tangan yang menyatu atau (smile) senyum yang santun. guru tentu akan lebih memahami dan merasa lebih dihargai dengan adanya emoticon pendukung tersebut. Namun sebaliknya, jika emoticon tidak dicantumkan pada tempat yang tepat maka, akan terkesan menyepelekan/ tidak sopan serta berlebihan tentu akan merusak makna dan mengurangi nilai kesantunan.

Berdasarkan analisis dapat disilmpulkan bahwa gaya bahasa siswa dalam berkomunikasi dengan guru di WhatsApp menggunakan bahasa bilingual (campuran) dan bahasa non formal (santai). Kesantunan dalam berbahasa di media sosial tercermin dalam tatacara berkomunikasi lewat tanda non verbal (tulisan) dan tatacara berbahasa. Tuturan seperti itu tentunya mengurangi nilai kesantunan berbahasa karena lawan bicara siswa adalah guru yang harus dihormati. Dilihat dari struktur kalimat 
yang disusun oleh siswa di WhatsApp masih banyak yang tidak sesuai dengan tatanan struktur bahasa Indonesia yang benar. Siswa juga masih banyak menggunakan bahasa daerah dan bahasa gaul dalam berkomunikasi di WhatsApp. Hal ini dikarenakan adanya faktor lingkungan dan pergaulan siswa. Pemahaman siswa terhadap konsep bahasa dalam berkomunikasi di media sosial sangatlah minim, hal ini dikarenakan faktor lingkungan dan pengalaman siswa yang sangat terbatas sehingga siswa tidak bisa membedakan penggunaan gaya bahasa formal atau santai yang sesuai untuk menanggapi komunikasi dari guru di WhatsApp. Hal ini sejalan dengan hasil penelitian sebelumnya yang menyatakan bahwa siswa tidak dapat membedakan bahasa Indonesia baku dan bahasa santai karena kurangnya pemahaman siswa terhadap konsepsi bahasa Indonesia baku (Pratamanti et al., 2017).

\section{Pembahasan}

Berdasarkan hasil penelitian yang telah diajabrkan sebelumnya, dapat dikatakan bahwa sikap siswa dalam etika berkomunikasi di WhatsApp group adalah kurang baik. Hal ini disebabkan oleh beberapa faktor diantaranya adalah faktor keluarga dan faktor lingkungan sekitar siswa (faktor eksternal). Selain itu, faktor dari dalam diri siswa (faktor internal) juga mempengaruhi etika komunikasi siswa (Ahdan et al., 2020; Marlen \& Atmazaki., 2020). Mengingat adanya pembelajaran daring yang mengharuskan siswa mempunyai handphone sendiri sehingga siswa terbawa arus dengan bahasa-bahasa yang ada dalam jaringan yang telah diakses oleh siswa. Faktor yang menyebabkan siswa berkata tutur bahasa asing seperti "ok, cikgu" dilatarbelakangi oleh pergaulan dan media-media, seperti televisi dan internet. Kehadiran teknologi seperti televisi dan internet menghadirkan berbagai fasilitas didalamnya sehingga membuat siswa kurang mengetahui etika mana yang cocok digunakan untuk melakukan komunikasi yang baik. Media hadir sebagai pemberi contoh kepada siswa dalam dunia pendidikannya. Media ini sangat mempengaruhi etika komunikasi siswa. Disamping itu, pengaruh lain dari etika komunikasi siswa adalah pengaruh kebiasaan di masyarakat (lingkungan) dan wawasan dari siswa itu sendiri.

Lingkungan merupakan segala sesuatu yang berhubungan dan berpengaruh terhadap diri siswa. Dalam kata lain, lingkungan adalah sesuatu yang berpengaruh terhadap perkembangan manusia untuk saling berinteraksi dengan sesama (Ahmad \& Mustika, 2021; Ariati, 2017; Lonanda et al., 2015). Secara umum bahasa yang digunakan siswa dalam menanggapi percakapan di WhatsApp adalah bahasa daerah (jawa). Hal ini merupakan bentuk faktor lingkungan yang mempengaruhi tata tutur berbahasa siswa. Apabila siswa menanggapi dengan bahasa krama (Jawa) terdapat kemungkinan bahwa siswa sering berinteraksi menggunakan bahasa tersebut dengan keluarga atau masyarakat sekitar (lingkungan). Faktor keluarga dan faktor lingkungan memiliki peran yang sama dalam mempengaruhi etika komunikasi siswa terhadap guru. Orang tua merupakan faktor utama dari sisi keluarga dalam menentukan karakter seorang anak (siswa) (Daheri et al., 2020; Jannah \& Umam, 2021; Yulianingsih et al., 2020). Lingkungan memiliki peran dominan dalam membentuk dan mempengaruhi karakter dari setiap siswa. Masyarakat merupakan lingkungan dimana siswa berada sehingga mudah untuk mempengaruhi pembentukan karakter dalam etika berkomunikasi.

Penelitian sebelumnya juga menyatakan bahwa bahwa etika komunikasi siswa yang sebenarnya adalah mereka yang telah berada, hidup dan berkembang dalam lingkungan masyarakat (Fahrimal, 2018; Fauziyyah, 2019; Junaidi, 2018). Oleh karena itu dalam masyarakat siswa hendaknya mampu melakukan komunkasi dengan menggunakan bahasa yang sopan. Terlebih saat menggunakan media online seperti whattsap diharapkan siswa mampu menggunakan media online dengan bijak. Untuk dapat melakukan komunikasi dengan baik, perilaku dan adab adalah kunci utamanya. Walaupun whatsApp membuat mahasiswa lebih mudah untuk saling berinteraksi dan berbagi informasi di dalam Group WhatsApp. Mahasiswa dituntut memperhatikan bahasa dan etika ketika berkomunikasi. Selain orang tua guru uga harus mampu memberikan contoh bagaimana etika yang baik dalam berkomunikasi lewat media online agar kedepannya hal tersebut dapat dijadikan bekal oleh siswa agar menjadi pribadi yang sopan, saling menghormati dan disiplin (Apriyanti, 2019; Jannah \& Umam, 2021; Rachmadyanti, 2017).

\section{SIMPULAN}

Etika berkomunikasi siswa dengan guru dalam pembelajaran daring melalui aplikasi media sosial WhatsApp dinyatakan kurang baik. Siswa jarang memberikan feedback (respon) terhadap informasi tugas maupun materi yang diberikan guru. Sikap siswa dalam etika berkomunikasi di WhatsApp dengan guru menunjukkan sikap respon yang kurang baik. Siswa jarang memberi tanggapan informasi yang diberikan oleh guru. Tata penulisan siswa dalam berkomunikasi dengan guru di WhatsApp cukup baik karena siswa sudah tepat dalam menggunakan emoticon maupun stiker. Akan tetapi penggunaan tanda baca dan ejaan dalam menulis terkadang siswa masih melakukan kesalahan. 


\section{DAFTAR RUJUKAN}

Abroto, Anantama, \& Prastowo. (2021). Analisis Hambatan Proses Pembelajaran Daring dengan Menggunakan Aplikasi Whatsapp di Sekolah Dasar. Jurnal Basicedu, 5(3), 1632-1638. https://doi.org/10.31004/basicedu.v5i3.971.

Afifah, N. (2019). Efektivitas Media Ajar untuk Siswa Kelas Rendah Berbasis Nilai Karakter Toleransi terhadap Sesama dengan Berbantu Aplikasi Sparkol Videoscribe. Modeling: Jurnal Program Studi PGMI, 6(2). https://doi.org/10.36835/modeling.v6i2.512.

Agustina, M., Azizah, E. N., \& Koesmadi, D. P. (2021). Pengaruh Pemberian Reward Animasi terhadap Motivasi Belajar Anak Usia Dini selama Pembelajaran Daring. Jurnal Obsesi : Jurnal Pendidikan Anak Usia Dini, 6(1), 353-361. https://doi.org/10.31004/obsesi.v6i1.1331.

Ahdan, S., Putri, A. R., \& Sucipto, A. (2020). Aplikasi M-Learning Sebagai Media Pembelajaran Conversation Pada Homey English. Sistemasi, 9(3), 493. https://doi.org/10.32520/stmsi.v9i3.884.

Ahmad, F., \& Mustika, D. (2021). Problematika Guru Dalam Menerapkan Media pada Pembelajaran Kelas Rendah Di Sekolah Dasar. Jurnal Basicedu, 5(4), 2008-2014. https://doi.org/10.31004/basicedu.v5i4.1056.

Andarwulan, T., Al Fajri, T. A., \& Damayanti, G. (2021). Elementary teachers' readiness toward the online learning policy in the new normal era during Covid-19. International Journal of Instruction, 14(3), 771-786. https://doi.org/10.29333/iji.2021.14345a.

Anugrahana, A. (2020). Hambatan, Solusi dan Harapan: Pembelajaran Daring Selama Masa Pandemi Covid-19 Oleh Guru Sekolah Dasar. Scholaria: Jurnal Pendidikan Dan Kebudayaan, 10(3), 282-289. https://doi.org/10.24246/j.js.2020.v10.i3.p282-289.

Apriyanti, H. (2019). Pemahaman Orang Tua Terhadap Pentingnya Pendidikan Anak Usia Dini. Education. Education Journal: Journal Educational Research and Development, 3(1). https://doi.org/10.31537/ej.v3i1.137.

Ariati. (2017). Urgensi Lingkungan Belajar Yang Kondusif Dalam Mendorong Siswa Belajar Aktif. Jurnal Kependidikan, 11(1). https://doi.org/10.30863/didaktika.v11i1.161.

Arizona, K., Abidin, Z., \& Rumansyah, R. (2020). Pembelajaran Online Berbasis Proyek Salah Satu Solusi Kegiatan Belajar Mengajar Di Tengah Pandemi Covid-19. Jurnal Ilmiah Profesi Pendidikan, 5(1). https: //doi.org/10.29303/jipp.v5i1.111.

Arnott, L., \& Yelland, N. (2020). Multimodal lifeworlds: Pedagogies for play inquiries and explorations. Journal of Early Childhood Education Research, 9(1), 124-146.

Arrosagaray, M., González-Peiteado, M., Pino-Juste, M., \& Rodríguez-López, B. (2019). A comparative study of Spanish adult students' attitudes to ICT in classroom, blended and distance language learning modes. Computers and Education, 134(October 2018), 31-40. https://doi.org/10.1016/j.compedu.2019.01.016.

Chang, T. Y., Hong, G., Paganelli, C., Phantumvanit, P., Chang, W. J., Shieh, Y. S., \& Hsu, M. L. (2020). Innovation of dental education during COVID-19 pandemic. Journal of Dental Sciences, 155. https://doi.org/10.1016/j.jds.2020.07.011.

Daheri, M., Juliana, J., Deriwanto, D., \& Amda, A. D. (2020). Efektifitas WhatsApp sebagai Media Belajar Daring. Jurnal Basicedu, 4(4), 775-783. https://doi.org/10.31004/basicedu.v4i4.445.

Dewi, P. A. S. C., \& Khotimah, H. (2020). Pola Asuh Orang Tua Pada Anak Di Masa Pandemi Covid-19. Seminar Nasional Sistem Informasi, 2433-2441.

Djuwita, P. (2017). Pembinaan Etika Sopan Santun Peserta Didik Kelas V Melalui Pembelajaran Pendidikan Kewarganegaraan Di Sekolah Dasar Nomor 45 Kota Bengkulu. Jurnal PGSD, 10(1), 27-36. https://doi.org/10.33369/pgsd.10.1.27-36.

Dumitrescu, C., Olteanu, R. L., Gorghiu, L. M., \& Gorghiu, G. (2014). Learning Chemistry in the Frame of Integrated Science Modules - Romanian Student's Perception. Procedia - Social and Behavioral Sciences, 116(September 2015), 2516-2520. https://doi.org/10.1016/j.sbspro.2014.01.603.

Dyah Purnama Sari, P. S. (2020). Efektivitas Pembelajaran Jarak Jauh Dengan Daring Selama Pandemi Covid-19 EFEKTIVITAS Mata Pelajaran Pendidikan Jasmani Olahraga Dan Kesehatan (PJOK). Pediatric Critical Care Medicine, 1022-1023. https://doi.org/10.1097/PCC.0000000000002513.

Fahrimal, Y. (2018). Netiquette: Etika Jejaring Sosial Generasi Milenial Dalam Media Sosial. Jurnal Penelitian Pers Dan Komunikasi Pembangunan, 22(1), 69-78. https://doi.org/10.46426/jp2kp.v22i1.82.

Fauziyyah, N. (2019). Etika Komunikasi Peserta Didik Digital Natives Melalui Media Komunikasi Online (Whatsapp) Kepada Pendidik: Perspektif Dosen. Pedagogik: Jurnal Pendidikan, 6(2). https://doi.org/10.33650/pjp.v6i2.750.

Fikri, M., Ananda, M. Z., \& Faizah, N. (2021). Kendala Dalam Pembelajaran Jarak Jauh di Masa Pandemi Covid-19: Sebuah Kajian Kritis. Jurnal Education and Development Institut Pendidikan Tapanuli 
Selatan, 9(1), 145-148. https://doi.org/10.37081/ed.v9i1.2290.

Fitria, Y., Hasanah, F. N., \& Gistituati, N. (2018). Critical Thinking Skills of Prospective Elementary School Teachers in Integrated Science-Mathematics Lectures. Journal of Education and Learning (EduLearn), 12(4), 597-603. https://doi.org/10.11591/edulearn.v12i4.9633.

Fitriyani, \& Sari. (2020). Motivasi Belajar Mahasiswa Pada Pembelajaran Daring Selama Pandemik Covid19. Jurnal Kependidikan: Jurnal Hasil Penelitian Dan Kajian Kepustakaan Di Bidang Pendidikan, Pengajaran, Dan Pembelajaran, 6(2), 165-175. https://doi.org/https://doi.org/10.33394/jk.v6i2.2654.

Glassman, M., Kuznetcova, I., Peri, J., \& Kim, Y. (2021). Cohesion, collaboration and the struggle of creating online learning communities: Development and validation of an online collective efficacy scale. $\begin{array}{llll}\text { Computers and } & \text { Education }\end{array}$ https://doi.org/10.1016/j.caeo.2021.100031.

Goudeau, S., Sanrey, C., Stanczak, A., Manstead, A., \& Darnon, C. (2021). Why lockdown and distance learning during the COVID-19 pandemic are likely to increase the social class achievement gap. Nature Human Behaviour. https://doi.org/10.1038/s41562-021-01212-7.

Gurung, R. A. R. (2020). Call It Out: Recognizing Good Teaching and Learning. Journal of Applied Research in Memory and Cognition, 9(2), 161-164. https://doi.org/10.1016/j.jarmac.2020.02.003.

Hutauruk, A., \& Sidabutar, R. (2020). Kendala pembelajaran daring selama masa pandemi di kalangan mahasiswa pendidikan matematika: Kajian kualiatatif deskriptif. Journal of Mathematics Education and Applied, 02(01), 45-51. https://doi.org/10.36655/sepren.v2i1.364.

Hwang, G. J., Wang, S. Y., \& Lai, C. L. (2020). Effects of a social regulation-based online learning framework on students' learning achievements and behaviors in mathematics. Computers and Education, 160, 104031. https://doi.org/10.1016/j.compedu.2020.104031.

Idris, I., \& Sida, S. C. (2019). Pengaruh Model Problem Based Learning Terhadap Keterampilan Proses dan Hasil Belajar IPS Siswa SD. Indonesian Journal of Primary Education, 3(2), 58-63. https://doi.org/10.17509/ijpe.v3i2.21849.

Jannah, N., \& Umam, K. (2021). Peran Orang Tua dalam Pendidikan Karakter Berbasis Keluarga di Masa Pandemi Covid-19. FALASIFA: Jurnal Studi Keislaman, 12(1), 95-115. https://doi.org/10.36835/falasifa.v12i1.460.

Jiang, H., Islam, A. Y. M. A., Gu, X., \& Spector, J. M. (2021). Online learning satisfaction in higher education during the COVID-19 pandemic: A regional comparison between Eastern and Western Chinese universities. Education and Information Technologies, 26(6). https://doi.org/10.1007/s10639021-10519-X.

Jogezai, N. A., Baloch, F. A., Jaffar, M., Shah, T., Khilji, G. K., \& Bashir, S. (2021). Teachers' Attitudes Towards Social Media (SM) Use in Online Learning Amid The COVID-19 Pandemic: The Effects of SM Use by Teachers and Religious Scholars During Physical Distancing. Journal Heliyon, 7(4), 1-9. https://doi.org/10.1016/j.heliyon.2021.e06781.

Junaidi, J. (2018). Analisis Etika Komunikasi Siswa Melalui Pendidikan Karakter Islam Di Sma Kota Tangerang Selatan. Edukasi Lingua Sastra, 16(2), 68-85. https://doi.org/10.47637/Elsa.V16i2.95.

Khaerunnnisa, E., \& Pamungkas, A. S. (2018). Pengembangan Instrumen Kecakapan Matematis Dalam Konteks Kearifan Lokal Budaya Banten Pada Materi Bangun Ruang Sisi Datar. Kreano: Jurnal Matematika Kreatif-Inovatif, 9(1). https://doi.org/10.15294/kreano.v9i1.11210.

Kintu, M. J., Zhu, C., \& Kagambe, E. (2017). Blended learning effectiveness : the relationship between student characteristics , design features and outcomes. International Journal of Educational, 14(7), 1-20. https://doi.org/10.1186/s41239-017-0043-4.

Kkese, E. (2020). McGurk effect and audiovisual speech perception in students with learning disabilities exposed to online teaching during the COVID-19 pandemic. Medical Hypotheses, 144(July), 110233. https://doi.org/10.1016/j.mehy.2020.110233.

Lonanda, S., Yolamalinda, \& Stevi. (2015). Pengaruh Kesiapan Belajar, Lingkungan Belajar Dan Peranan Orangtua Terhadap Hasil Belajar Ekonomi Siswa Kelas Ips Di SMA PGRI 4 Padang. Journal of

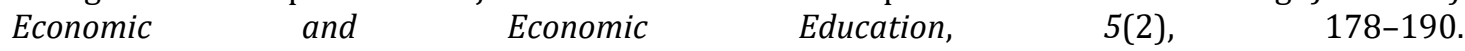
https://doi.org/10.1017/CB09781107415324.004.

Lyócsa, ̌̌., Baumöhl, E., Výrost, T., \& Molnár, P. (2020). Fear of the coronavirus and the stock markets. Finance Research Letters, 36. https://doi.org/10.1016/j.frl.2020.101735.

Marlen, \& Atmazaki. (2020). Kesantunan Berbahasa Siswa dengan Guru Bahasa Indonesia melalui Media Sosial WhatsApp di SMP Negeri 2 Bukittinggi. Jurnal Bahasa Dan Sastra Indonesia, 9(4), 1-12.

Maulana, H. A. (2021). Psychological Impact of Online Learning during the COVID-19 Pandemic: A Case Study on Vocational Higher Education. Indonesian Journal of Learning Education and Counseling, 3(2), 130-139. https://doi.org/10.31960/ijolec.v3i2.833. 
Mulyono, H., Suryoputro, G., \& Jamil, S. R. (2021). The application of WhatsApp to support online learning during the COVID-19 pandemic in Indonesia. Heliyon, 7(8), e07853. https://doi.org/10.1016/j.heliyon.2021.e07853.

Mustofa, M. I., Chodzirin, M., Sayekti, L., \& Fauzan, R. (2019). Formulasi Model Perkuliahan Daring sebagai Upaya Menekan Disparitas Kualitas Perguruan Tinggi. Walisongo Journal of Information Technology, 1(2), 151. https://doi.org/10.21580/wjit.2019.1.2.4067.

Mutiani. (2021). Pembinaan Etika Peserta Didik Melalui Pembelajaran Tematik - Integratif di Sekolah Dasar. Edukatif: Jurnal Ilmu Pendidikan, 3(3). https://doi.org/10.33369/pgsd.14.1.70-79.

Oktario, A. S., Ariesta, R., \& Gumono. (2019). Penggunaan Bahasa Dalam Pesan Whatsapp: Interaksi Multimodal. Jurnal Ilmiah KORPUS, 3(2), 131-136. https://doi.org/10.33369/jik.v3i2.10113.

Owusu-Fordjour, C., Koomson, C. K., \& Hanson, D. (2020). The Impact of Covid-19 on Learning-The Perspective of the Ghanaian Student. European Journal of Education Studies, 7(3), 88-101. https://doi.org/10.5281/zenodo.3753586.

Prasetyo, G., Hidayatullah, M. F., Akhyar, M., Wiranto, \& Perdana, R. (2020). Strengthening Students' Character Through Multimedia Learning In Primary Schools Education: Systematic Literatur. Humanities \& Social Sciences Reviews, 8(3), 268-277. https://doi.org/10.18510/hssr.2020.8328.

Pratamanti, E. D., Riana, R., \& Setiadi, S. (2017). Kesantunan Berbahasa Dalam Pesan Whatsapp Mahasiswa yang Ditujukan Kepada Dosen. Jurnal Dinamika Sosial Budaya, 19(2), 230-239. https://doi.org/10.26623/jdsb.v19i2.984.

Primasari, I. F. N. D., \& Zulela. (2021). Kendala Pembelajaran Jarak Jauh (PJJ) Secara Online Selama Masa Pandemik Covid-19 di Sekolah Dasar. JIKAP PGSD: Jurnal Ilmiah Ilmu Kependidikan, 5(1), 64-73. https://doi.org/10.26858/jkp.v5i1.16820.

Pujiasih, E. (2020). Membangun Generasi Emas Dengan Variasi Pembelajaran Online Di Masa Pandemi Covid-19. Ideguru: Jurnal Karya Ilmiah Guru, 5(1), 42-48. https://doi.org/10.51169/ideguru.v5i1.136.

Putria, H., Maula, L. H., \& Uswatun. D. A. (2020). Analisis Proses Pembelajaran Dalam Jaringan (DARING) Masa Pandemi COVID-19 pada Guru Sekolah Dasar. Jurnal Basicedu, 4(4), 861-872. https://doi.org/10.31004/basicedu.v4i4.460.

Rachmadyanti, P. (2017). Penguatan Pendidikan Karakter Bagi Siswa Sekolah Dasar Melalui Kearifan Lokal. Jurnal Pendidikan Sekolah Dasar, 3(2), 201-214. https://doi.org/10.30870/jpsd.v3i2.2140.

Rahma, N. A., \& Pujiastuti, H. (2021). Efektivitas Pembelajaran Daring Matematika Pada Masa Pandemi Covid-19 Di Kota Cilegon [the Effectiveness of Mathematics Online Learning During the Covid-19 Pandemic in Cilegon City]. JOHME: Journal of Holistic Mathematics Education, 5(1), 1. https://doi.org/10.19166/johme.v5i1.3811.

Riaz, A. (2018). Effects of Online Education on Encoding and Decoding Process of Students and Teachers. International Conference E-Learning, 42-48. https://doi.org/https: //files.eric.ed.gov/fulltext/ED590288.pdf.

Sa'diyah, H., Hastuti, A. F., \& Prasetiyo, W. H. (2020). Efektivitas Google Classroom dalam Pengelolaan Pembelajaran Masa Pandemi di SMA Negeri 1 Wonosari. 3, 120-125. https://doi.org/10.23917/blbs.v3i1.13893.

Sari, P. (2015). Memotivasi Belajar Dengan Menggunakan E-Learning. Ummul Qura, 6(2).

Sarjana, S., \& Khayati, N. (2017). Pengaruh Etika, Perilaku, Dan Kepribadian Terhadap Integritas Guru. Jurnal Pendidikan Dan Kebudayaan, 1(3). https://doi.org/10.24832/jpnk.v1i3.450.

Sukendro, S., Habibi, A., Khaeruddin, K., Indrayana, B., Syahruddin, S., Makadada, F. A., \& Hakim, H. (2020). Using an extended Technology Acceptance Model to understand students' use of e-learning during Covid-19: Indonesian sport science education context. Heliyon, 6(11), e05410. https://doi.org/10.1016/j.heliyon.2020.e05410.

Tamboto, H., Tambingon, H. N., Lengkong, J. S. ., \& Rotty, V. N. J. (2021). The Involvement of Students' Parents in Organizing the Learning from Home at Elementary Schools in Tomohon City. Asia Pacific Journal of Management and Education, 4(1), 35-51. https://doi.org/10.32535/apjme.v4i1.1044.

Trisnani. (2017). Pemanfaatan Whatsapp Sebagai Media Komunikasi dan Kepuasan dalam Penyampaian Pesan Dikalangan Tokoh Masyarakat. Komunikasi, Media Dan Informatika, 6(November). https://doi.org/10.31504/komunika.v6i3.1227.

Yulia, H. (2020). Online Learning to Prevent the Spread of Pandemic Corona Virus in Indonesia. ETERNAL (English Teaching Journal), 11(1). https://doi.org/10.26877/eternal.v11i1.6068.

Yulianingsih, W., Suhanadji, S., Nugroho, R., \& Mustakim, M. (2020). Keterlibatan Orangtua dalam Pendampingan Belajar Anak selama Masa Pandemi Covid-19. Jurnal Obsesi : Jurnal Pendidikan Anak Usia Dini, 5(2), 1138-1150. https: //doi.org/10.31004/obsesi.v5i2.740. 